\title{
IV Harrison Lecture 1981: the international venereological scene as viewed by Harrison and St Mary's*
}

\author{
R R WILLCOX \\ From St Mary's Hospital, London
}

\section{Introduction}

Venereology has always had its international aspects extending back through the time when each country in Europe blamed another for the introduction of syphilis at the end of the fifteenth century to as far as Biblical times. ${ }^{1}$ Notable early legislation with international relevance affecting the venereal diseases was the Copenhagen regulations of 1802 , which provided for the free treatment of foreign seamen, ${ }^{2}$ but the starting point for multinational agreement and cooperation in matters of health was the Geneva convention of 1864 , which regulated the management of the wounded in war.

\section{Founding of the London Lock Hospital}

This was originally founded by William Bromfield (fig 1), a surgeon at St George's Hospital, near Hyde Park Corner, in 1746 (fig 2). ${ }^{34}$ It was concerned not only with the treatment of venereal diseases but also with the moral welfare and rehabilitation of patients. The Lock Hospital was moved to the Harrow Road in 1842 to a site purchased from the executors of the late Sarah Siddons, the actress; its outpatient department was opened a few years later in Dean Street. The hospital's imposing chapel was consecrated in 1847 with a resident chaplain, the Reverend $T$ Garnier, later Dean of Lincoln, ${ }^{5}$ who was also appointed to the immediately adjacent Paddington workhouse, which opened in the same year. ${ }^{6}$ The workhouse was later to be integrated into an expanded Paddington Infirmary, now St Mary's Hospital. The site of the present postgraduate centre is where the chapel once stood.

\footnotetext{
* Shortened version of the lecture delivered to the MSSVD at the Wright-Fleming Institute, St Mary's Hospital, London, 26 June 1981
}

Address for reprints: Dr R R Willcox, Tideway, Lonsdale Road, London SW13

Accepted for publication 8 September 1981

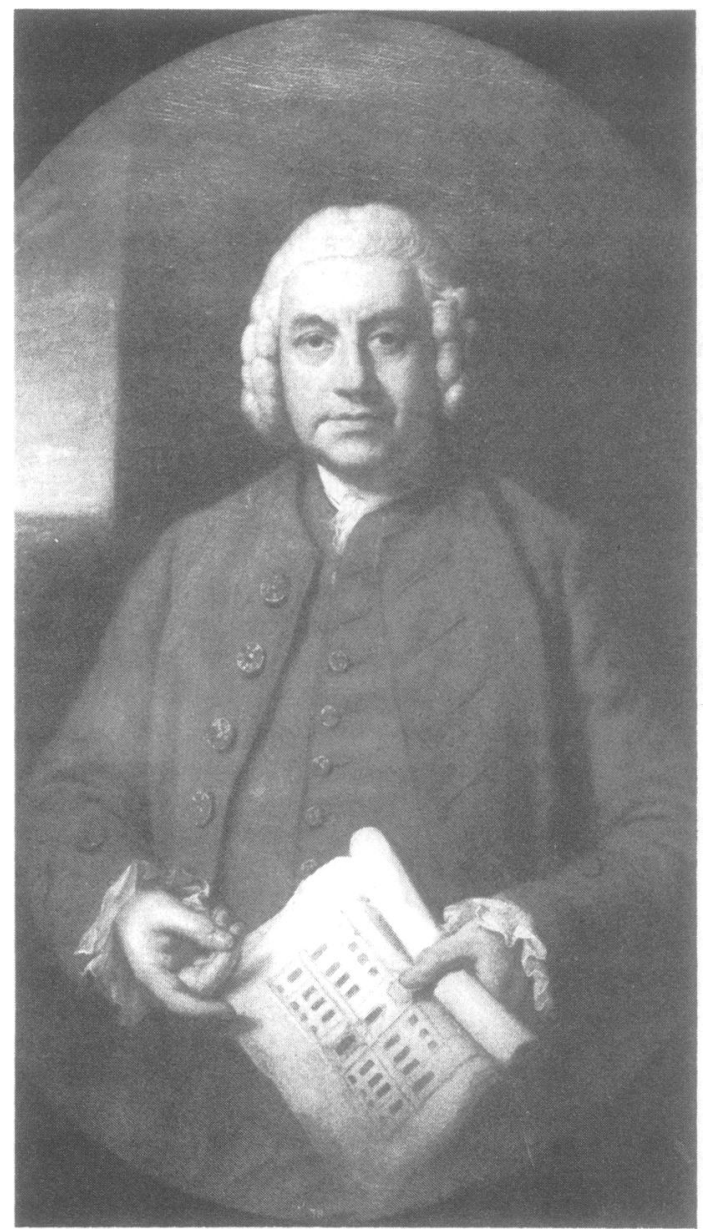

FIG 1 William Bromfield

\section{Founding of St Mary's Hospital}

St Mary's Hospital in Praed Street opened in $1851 \AA$ and the medical school three years later. Samuelo 


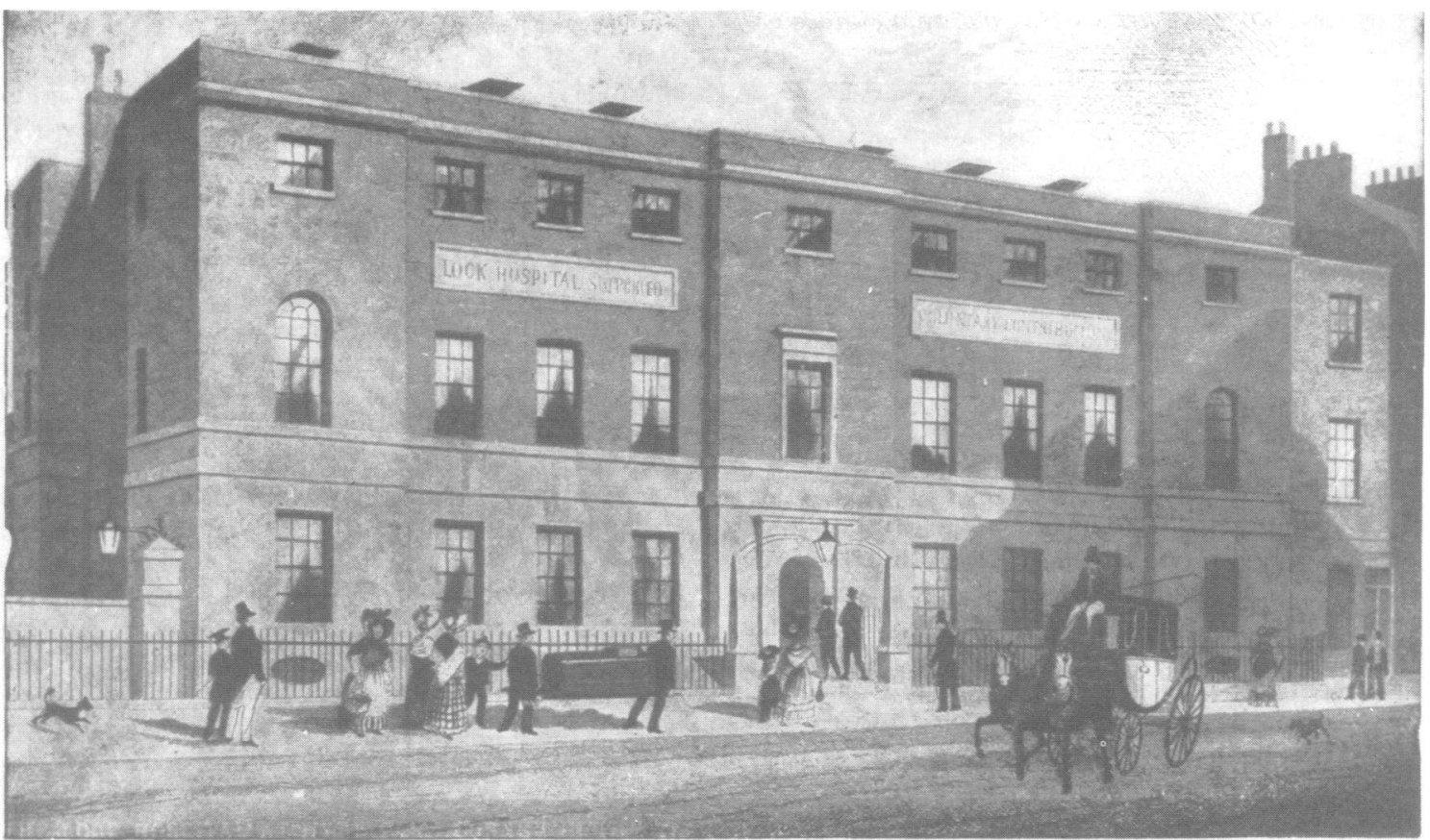

THE LOCK HOSPITAL AT HYDE PARK CORNER IN THE TIUE OP WATERLOO, 1815. TOTAL NUMBER OF BEDS IN 1815.78. FIG 2 Original Lock Hospital near Hyde Park Corner, London

Armstrong Lane (1802-92) (fig 3), having been unable to get on the staff of St George's Hospital, was undoubtedly the chief person concerned in the founding of the medical school. ${ }^{7}$

The ties between St Mary's and the Lock hospitals were close (table I). Besides Samuel Lane, three others on the original staff of St Mary's were also on the staff of the Lock, including William Coulson, who founded the Hospital for Stone (St Peter's), which provided an early link between venereology and urology, and Samuel Lane's nephew, James Robert Lane.

\section{SYPHILISATION}

A striking example of international co-operation at the time took place at the Lock Hospital in 1865. A peculiar method of treatment, syphilisation, involved repeated inoculation of so-called syphilitic matter from other patients into those already having syphilis. It was originated by Auzias Turenne in Paris in about 1845 and resulted in much opposition and ridicule. It was, however, adopted for a time by Sperino of Turin with varied success and then on a large scale by Professor Carl Wilhelm Boeck (of Oslo), uncle of Professor Caesar Boeck of sarcoid and Boeck-Brusgaard material fame, who succeeded him. While on a professional visit to this country

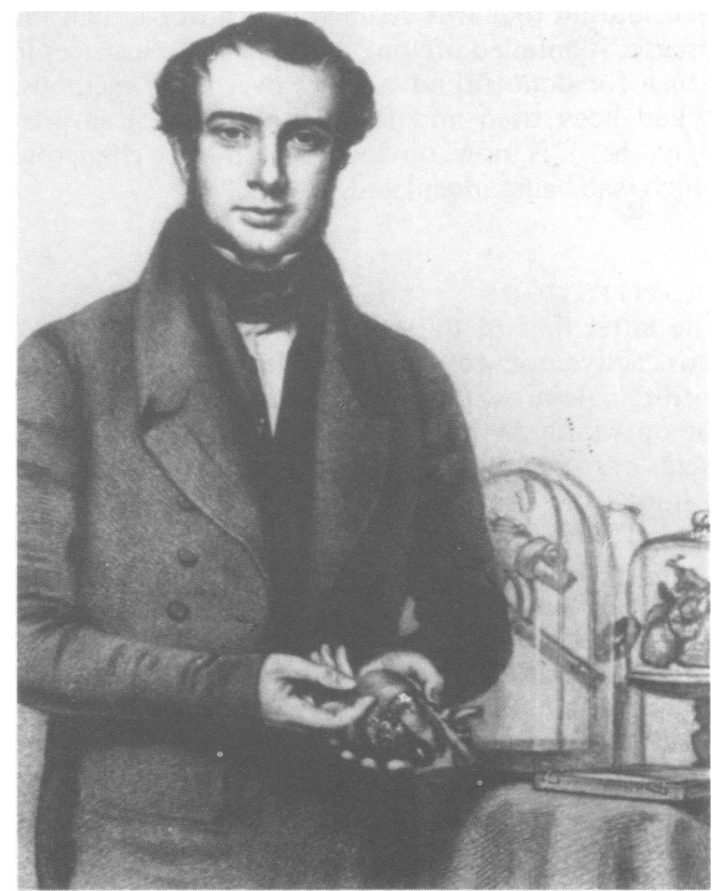

FIG 3 Samuel Lane 
TABLE I Staff of St Mary's Hospital, who also served at the Lock Hospital

\begin{tabular}{lllll}
\hline Name & Born & Died & Specialty & Appointed \\
\hline S A Lane & 1802 & 1877 & Surgeon & 1854 \\
W Coulson & 1802 & 1887 & Surgeon & 1854 \\
E Sieveking & 1816 & 1904 & Physician & 1854 \\
J R Lane & 1825 & 1891 & Surgeon & 1854 \\
G G Gascoyen & 1830 & 1876 & Surgeon & 1864 \\
W J Coulson & 1834 & 1899 & Surgeon & 1865 \\
H E Juler & 1842 & 1921 & Eye surgeon & 1884 \\
S Phillips & 1851 & 1951 & Physician & 1884 \\
J E Lane & 1857 & 1926 & Surgeon & 1891 \\
\hline
\end{tabular}

Boeck was invited by the Admiralty to state his views to a committee inquiring into the treatment and prevention of venereal diseases in the Army and Navy. He offered to initiate treatment by syphilisation if sufficient hospital accommodation could be made available. Beds were provided at the Lock Hospital and he came in August 1865 and stayed until the end of the year. Treatment was then continued by $\mathbf{J}$ R Lane and C G Gascoyen, who later published the results. ${ }^{8}$

The total number of inoculations made in 27 patients was 6993 and the mean number of those successful was 145 (range 66-296). A decade later in 1876-the year Harrison was born-Lane wrote in his Harveian Lectures on Syphilis ${ }^{9}$ that if the treatment did all that was claimed it was worse than the disease. It entailed lifelong marking with cicatrices in return for doubtful advantages over other methods. It had been tried and found wanting; not surprisingly, as it is now obvious that it was chancroid which was being inoculated.

\section{PROSTITUTION}

The latter half of the century was undoubtedly the most active ever for the Lock Hospital; it was filled with female prostitutes from garrison towns through the operation of the Contagious Diseases Prevention Acts of 1864-9.10 These gave legal approval to Britain's only serious attempt to regulate prostitution. Those found to be 'common prostitutes' in ultimately some 19 garrison towns were compelled to be medically examined; those infected were detained in a Lock hospital for up to three months. A special force of plain clothes officers was established to administer the Acts. ${ }^{10}$

Hardly were these laws established before the campaign against them grew (associated with the name of Josephine Butler); this had a marked influence on public opinion abroad. In 1875 an international federation was formed in Liverpool with the clumsy title 'The British, Continental, and General
Federation for the Abolition of Government Regula $\stackrel{\widehat{\Phi}}{\stackrel{\leftarrow}{\Phi}}$ tion of Prostitution' (later changed to the Inter- national Abolitionist Federation). Its first inter $\frac{}{6}$. national congress two years later was widely: attended. The Acts were condemned by Parliamen in 1883 and formally repealed in 1886.

Meanwhile, a movement for the suppression of the5 so-called white slave traffic grew in strength. Belgium had become the centre of the European market $\Phi^{\circ}$ Through the efforts of Mrs Butler, General Booth of the Salvation Army, the journalist W T Stead, and? others this was exposed and international feeling $\vec{D}$ aroused. ${ }^{11}$ After a conference in Brussels in 1899 convened by the International Vigilance Associations the French Government took the initiative in 1902 in? calling an official meeting, which resulted in 1904 inis the signing of an international agreement by delegates of 12 nations to monitor the situation. This led to the international convention which made the procuration of women and girls punishable by law. ${ }^{12}$

\section{0 - First World War}

The first decade of the new century was marked by 유 cascade of new discoveries of the cause, diagnosis and treatment of syphilis, which also brought tha 5 pioneer of immunology, Sir Almroth Wright (1861-1947), to St Mary's in 1902. Wright was क⿺ friend of Metchnikoff and particularly of Ehrlich. ${ }^{13} \overrightarrow{\vec{P}}$

Harrison was taught by Wright, who had earlier held the chair of pathology in the Army Medicab School, then at Netley, and regarded him as a great: teacher. ${ }^{14}$ Years later, during his first presidentia address to the MSSVD he stated, 'I feel keenly the debt which I owe to the training in laboratory methods of attacking problems which I received for only too short a time from Sir Almroth Wright and? later from my brother.' 15

The new discoveries were quickly taken up by the inoculation department at St Mary's. Alexande Fleming (1881-1955), who had joined Wright's. laboratory in 1906, was considerably involved. In 1909 he described the use of Hecht's modification of the Wassermann test, in which the serum to be testec? furnished both complement and amboceptor but ${ }^{\omega}$ with Scottish frugality, he modified it still further soe that only a small quantity of serum was required.$^{16}$ Irfe 1910, with Colebrook, he began to use salvarsan and in the following year they jointly described 46 cases in which this new drug - obtained from Ehrlich himself while on one of his visits to Wright's laboratory-had been injected in the wards of St Mary's. ${ }^{17} \frac{\mathrm{D}}{\mathrm{D}}$ They also used the drug in private practice and this contributed to the easing of Fleming's finances. ${ }^{18} 19$ O 


\section{L'OFFICE INTERNATIONALE D'HYGIÈNE} PUBLIQUE

With the increasing number of scientific congresses which had followed in the wake of the steamship and train the need was gradually felt for more permanent bureaux to record and implement decisions. By 1912 there were 510 such bureaux covering trade, agriculture, postal services, and health. ${ }^{20}$ The bureau for communicable diseases, l'Office Internationale d'Hygiène Publique, was established by international arrangement in Paris in 1907. Its bulletin was published monthly in French and consisted of reports concerning health legislation, some original articles, but mainly abstracts of papers relating to disease prevention-in many ways similar to the Bulletin of (now Abstracts on) Hygiene published by the Bureau of Hygiene and Tropical Diseases attached to the London School of Tropical Medicine.

ROYAL COMMISSION ON VENEREAL DISEASE In 1913 the Royal Commission was set up to inquire into the true prevalence of venereal diseases in Britain, their effects on the health of the community, and how these could be alleviated or prevented. ${ }^{21}$

Two of St Mary's staff, the surgeon J E Lane (the son of James Robert Lane and also at the Lock Hospital) and Sir Malcolm Morris, the hospital's first dermatologist and an internationally renowned figure (whose interest in syphilis had resulted in a paper on salvarsan in the treatment of syphilitic glossitis in 1912 and who in the same year outlined in the Lancet a plea for the establishment of such a commission) served as members. James Pringle, dermatologist at the Middlesex Hospital, gave evidence among a number of prominent physicians which included Sir William Osler, and written statements were supplied by the recently promoted Colonel Harrison. Two international experts, Dr Svend Lomholt of Denmark and Dr Santoliquido of Italy both testified that if facilities were freely available there was no problem with 'quacks'.

The Commission reported in 1916 and its main recommendations were embodied in the VD Regulations of the following year. Harrison, starting at St Thomas's Hospital in 1919 and now technical adviser to the Ministry of Health, was naturally much involved in their implementation. ${ }^{22}$

\section{SITUATION AT ST MARY'S HOSPITAL}

Venereal diseases had previously been treated in the general surgical outpatients, but a separate clinic was established in 1916. Statistics were reported from 1917 onwards, and the returns of cases for 1919 and 1920 were signed by J E Lane. Although the pathology reports usually bore the signature of Captain $A$ F Hayden, who served the clinic for many years, the half-yearly pathology return for 1919 was nevertheless signed by Fleming, who was obviously still concerned in this field.

When the Wassermann reaction became essential, Lane (by now senior surgeon at the Lock) had had Fleming appointed there to do the blood tests. ${ }^{4}$ Although he first used his own modification of the test (Fleming's reaction) he later discarded this on finding it less reliable. He resigned from the Lock in 1919.

J E Lane also continued in charge at St Mary's until 1923 when he sustained a fractured femur when knocked down by a bus in Regent Street. The fracture did not heal and he died after three years in the Star and Garter Home at Richmond. A picture survives of him during the First World War, when for a time he was in charge of the American Military Hospital at Paignton in Devon, his most distinguished international role (fig 4).

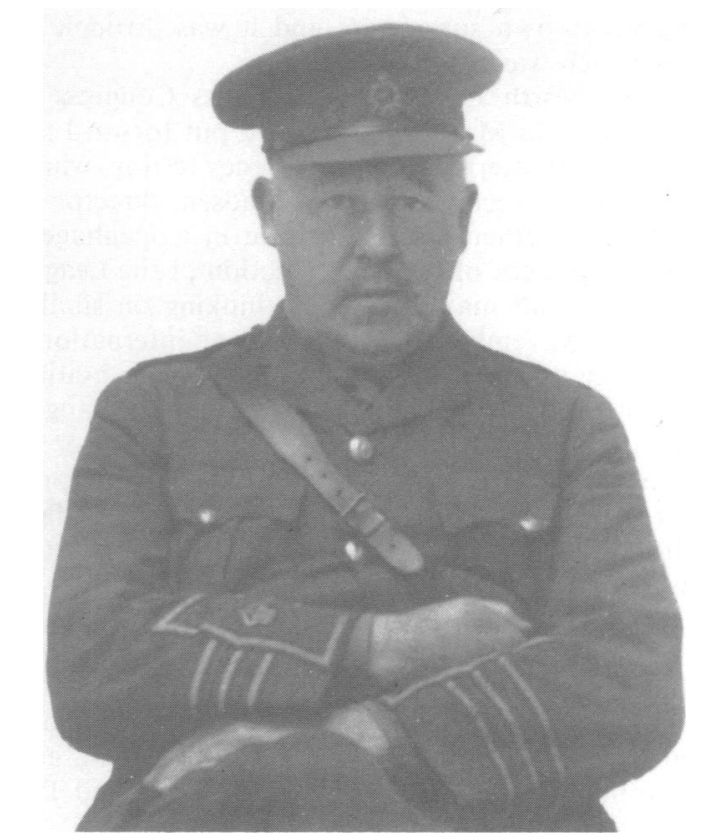

FIG 4 J E Lane

\section{Between the World Wars}

FORMATION OF THE LEAGUE OF NATIONS As envisaged by the Treaty of Versailles the League of Nations was formed in 1919 with financial, economic, and transit committees and a technical health committee. The last was concerned with the standardisation of drugs and sera. It was also respon- 
sible for the exchange of knowledge on communicable diseases and arranged missions to the Middle and Far East, Russia, and South-east Europe. In addition, by the generosity of the Rockefeller Foundation, it was made possible for health administrations to send officers to study methods in other countries, participating in practical work and meeting afterwards to discuss their findings in Geneva.

The Health Organisation also maintained an epidemiological intelligence service publishing worldwide data on epidemic diseases. It was noted, however, that the pre-existing bureau showed no eagerness to surrender its autonomy when maintaining contact with the League of Nations office. ${ }^{23}$

STANDARDISATION OF LABORATORY TESTS In the period after the First World War, after many previous attempts, effective flocculation tests for syphilis were being introduced which were much simpler than complement-fixation procedures. Each test had its own supporters and it was difficult to know which was best.

At the North European Red Cross Congress in Copenhagen in May 1921 Harrison put forward the suggestion of international proficiency testing, which was taken up keenly by Dr Th Madsen, director of the State Serotherapeutic Institute in Copenhagen. He was president of the health section of the League of Nations and may have been thinking on similar lines. ${ }^{24}$ In November of that year at an international conference under the auspices of the Standardisation Committee of the League of Nations it was arranged that the same sera should be tested in a number of European laboratories by three flocculation procedures following the precise techniques of their authors and by the local modification of the Wassermann reaction.

Harrison, now at the Ministry of Health, arranged for Dr E J Wyler (who worked at the Ministry's Public Health Laboratory, the forerunner of what is now the Reference Laboratory, and who would have used the Harrison-Wyler modification of the Wassermann) to go to Heidelberg, Oxford, and The Hague to master each author's requirements.

The results were presented in Paris in 1922 and a further conference was convened in Copenhagen the following year to arrange for the testing of the same approximately 530 sera by other European laboratories. At a later conference, held in Montevideo in 1928 and attended by both Wyler and Reuben Kahn, some 996 sera and 200 samples of cerebrospinal fluid were tested by South American workers. ${ }^{25}$ The newer Kahn test emerged the equal of the Wassermann.

These conferences were considered by Harrison to be 'great disillusioners'. They clearly showed that not only did workers not obey agreed protocol but mean- $-\frac{\mathbb{\Phi}}{\overparen{D}}$ ingful comparisons of results between laboratories were not yet possible and that some of the tests other than the Kahn were 'sadly wanting in reliability' ${ }^{24}$

FORMATION OF THE INTERNATIONAL UNION The Union Internationale contre le Péril Vénérien (IUPV), as it was then called, was formed in Paris in 1923; our own national society, the MSSVD, was established in London during the previous year. The British Journal of Venereal Diseases made its first $\overrightarrow{0}$ appearance in $1925 .^{26}$

BRUSSELS AGREEMENT

Apart from prostitutes the largest high-risk group inoo those days was merchant seamen. The need for making free treatment facilities available to seafarers regardless of nationality, and of standardising? control methods in ports, had been appreciated formany years. Indeed Denmark had been the first country to move in this direction as far back as 1802 . The newly established (1919) League of Red Cross Societies discussed the problem in Geneva, , Copenhagen, Prague, and Paris in $1920-1$ by which time Britain was already providing free treatment too sailors regardless of nationality.

When the Brussels agreement finally emerged in 1924, to be administered by l'Office Internationale d'Hygiène Publique in Paris, it was the culmination of the post-war activities of a number of inter- $\overrightarrow{\overrightarrow{0}}$ national organisations, including the InternationaP Labour Office (ILO) (also established in 1919), the Maritime Commission, the Health Organisation of the League of Nations, and the Union Internationale $\stackrel{\text { sen. }}{=}$. contre le Péril Vénérien. It was signed by $14 \overline{0}$ countries, ratified by 11 , and the number adhering to. it later increased to 56.

LEAGUE OF NATIONS COMMITTEE OF EXPERTS Reponding to the need for authoritative recommend $\frac{D}{O}$ ations for the treatment of syphilis the Health Organisation of the League of Nations convened a $\mathrm{N}$ Committee of Experts on Syphilis and Cognate Subjects in 1928 under the chairmanship of Professor J Jadassohn, then director of the Dermatology Clinic ${ }^{\mathrm{C}}$ at Breslau, and a member of the League's Health Committee, as president. Other members included읃 Dr John Stokes of Philadelphia, Professor Rasch of Copenhagen, Professor Louis Quéyrat (of erythro-:plasia fame, then president of the Ligue Nationale $\frac{0}{0}$ Française contre le Péril Vénérien), Dr Th Madsen, and Colonel Harrison. Professor $H$ Gougerot of $\frac{\mathscr{Q}}{\mathbb{D}}$ Paris and Dr Svend Lomholt of Copenhagen joined later. 
The experts recommended that a retrospective cooperative study should be carried out of the cases of syphilis treated in different countries using cards designed for the purpose to provide a basis for the recommendations. Some 25200 cards were ultimately obtained from Denmark, France, Germany, Britain, and the USA, in which countries the study was concentrated. Britain contributed just over $\mathbf{3 5 0 0}$ with a very wide distribution (table II). St Mary's and the Lock were regrettable absentees. The analysis was entrusted to Professor Hans Martenstein of Dresden who concentrated on the 13200 cards relating to secondary syphilis, of which nearly 2000 had to be discarded, as insufficient laboratory tests had been used. His findings were not forthcoming until November 1934 and the full report of the Committee of Experts was published in the Quarterly Bulletin of the Health Organization in March 1935 and was reviewed extensively by Harrison. ${ }^{27}$

TABLE II League of Nations syphilis inquiry: "top ten" of 28 British participating clinics (3571 cards)

\begin{tabular}{llll}
\hline St Thomas's, London & 955 & Wolverhampton & 195 \\
Guy's, London & 300 & British Army & 186 \\
Newcastle & 247 & Brighton & 136 \\
Dundee & 243 & Portsmouth & 134 \\
Bradford & 230 & Edinburgh & 111 \\
\hline
\end{tabular}

The Committee laid down the principles to be followed in arsenic and bismuth therapy, most of which have considerable relevance today. The data, however, did not allow a clear decision on the relative merits of the methods used.

Meanwhile, some 50 yards from here, in the year the Committee first sat, an event occurred which was of universal significance and which was to render its deliberations largely redundant. While Captain Hayden still performed the blood tests for the clinic, Fleming had discovered penicillin. ${ }^{28}$

POST-WAR YEARS AT ST MARY'S

After the death of $J E$ Lane the long association between the staff of St Mary's and the Lock ended. The Lock staff were now mainly surgeons with a urological background and included the redoubtable J Johnston Abraham (1876-1963), an almost exact contemporary of Harrison, with whom the Lock came to be so closely identified. St Mary's students went to the Lock, however, for teaching, as later did I. At St Mary's, the venereal disease clinic continued to be run by surgeons, namely $\mathrm{C} \mathrm{W}$ Gordon Bryan and R M Handfield Jones, acting on Bryan's behalf.

A crisis came in 1932, the year after I came as a student, when the London County Council indicated that they might not continue their financial support unless the clinic remained open all day with a medical officer in attendance, that it was under the control of one person who should have charge of both syphilis and gonorrhoea, and that it was conducted in suitable premises especially designed for the purpose.

The LCC's conditions were met and on 1 June 1933 Dr G L M McElligott (1897-1972) (fig 5) who had been clinical assistant with Colonel Harrison at St Thomas's Hospital, and more recently in charge of the clinic at Stoke on Trent, was appointed director on a salary of $£ 400$ a year. Arthur Porritt, who later as Lord Porritt served as Governor-General of New Zealand, was made assistant director. In 1936 he was succeeded by another surgeon, Mr A J Cokkinis, who had earlier been a surgical registrar at the Lock.

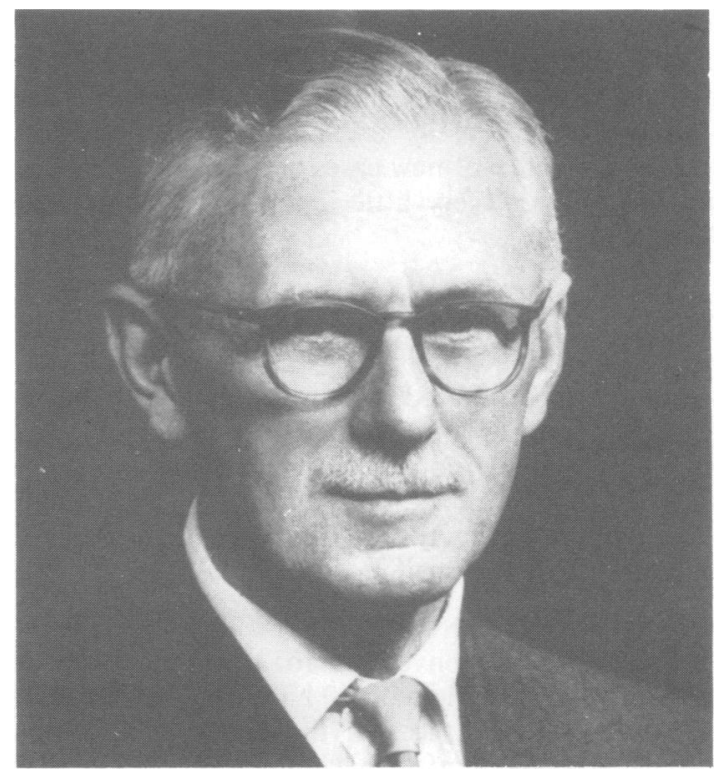

FIG 5 G L M McElligott

Accommodation was found in the basement of the old building and was enlarged by extending the premises into the yard behind; these were to serve as a VD clinic for over $\mathbf{4 0}$ years until, with Dr Jefferiss and myself, it was moved into its present purposebuilt premises some nine years ago. ${ }^{29}$

Dr McElligott established St Mary's as the first British full-time venereal disease clinic, although it was not until after the war that this became a reality.

\section{INTERNATIONAL VD STUDY GROUPS}

Another international pattern was set in 1935 when an investigatory group from New York visited Denmark, Sweden, and Britain to study antivenereal disease measures in these countries. In their report, ${ }^{30}$ which recognised the value of free venereal disease 
services in Europe, Britain was compared somewhat unfavourably with Sweden and Denmark where laws on compulsory treatment, punishment for transmission of infection, and prevention of marriage of infected persons were in force.

Harrison was not unnaturally critical of this report, as like was not compared with like in the quoted statistics, and arranged an official mission of his own in 1937 to visit Denmark, Norway, Sweden, and Holland. One of its four members was Dr Margaret Rorke, consultant venereologist at the Royal Free Hospital. The official report, a model of its kind, had Harrison as its first author. ${ }^{31}$ His own account of this mission, given to the MSSVD to inaugurate his unique second term as president, ${ }^{32}$ concluded that the Scandinavian antivenereal laws worked smoothly, did not lead to concealment of disease, and had undoubtedly led to a reduction in the incidence of syphilis, although despite them, that of gonorrhoea was still very high. He calculated too that the incidence of new cases of syphilis in England and Wales was "very little if any" greater than in Denmark.

RHINE BOATMEN

The need for co-operation between the countries bordering on the Rhine waterway and the establishment of a co-ordinated system for the treatment of venereal diseases for the Rhine boatmen was discussed by the Union Internationale contre le Péril Vénérien at their General Assembly in Amsterdam in 1936. An international sub-committee to co-ordinate such efforts was formed. ${ }^{33}$

\section{TRAFFIC IN WOMEN AND CHILDREN}

The international convention for the suppression of the white slave traffic of 1910 had been concluded in 1921 under the auspices of the League of Nations with its new title 'Traffic in women and children' and a special body of experts was appointed to monitor the subject. ${ }^{12} \mathrm{~A}$ further convention in 1933 aimed at the suppression of such traffic in women of full age. By 1937 a draft convention was prepared by the League with the object of securing concerted international action for the abolition of licensed houses and for the prosecution of those managing a brothel or exploiting the prostitution of others. It was planned that this should be concluded at an international convention in 1940 but the Second World War prevented this. The matter was taken up again by the Economic and Social Council of the United Nations (UNESCO) after the war and finally led to the adoption of the Convention for the Suppression of the Traffic in Persons and of the Exploitation of Prostitution of Others. ${ }^{34}$ The League's active interest in prostitution nevertheless continued. In the middle of the Second World War its advisory committee on social questions published a report on the prevention $\frac{\delta}{\Phi}$ of prostitution particularly with regard to minors. ${ }^{35} \stackrel{\mathbb{C}}{-}$

\section{Second World War}

WAR TIME AT THE LOCK

The outbreak of war, however, brought the Lock Hospital a flourishing new but terminal role as the $\frac{\bar{c}}{\bar{c}}$ Military Isolation Hospital, Harrow Road, for the $\frac{\bar{\Phi}}{\mathrm{d}}$ treatment of both skin (there was much scabies) and $\varrho$ venereal diseases. The VD specialist, who lateris became a dermatologist, was Major James Marshall, $\overrightarrow{0}$ formerly pre-war registrar at the same hospital, while at the War Office Harrison's St Thomas's patholo- $\vec{\sigma}$ gist, Brigadier T E Osmond, was adviser.

The chapel was deconsecrated and on Sundays its: gallery no longer housed the uniformed female patients deliberately obscured from public view, $\stackrel{N}{N}$ being used only for an occasional ENSA party, $N$ members of which would look quizzically when they음 learnt that the boys in blue they were going to enter- tain had been wounded in an unusual place.

The wards were filled with patients with epididymitis and arthritis, but above all with hepatitis $\vec{\oplus}$ which affected $50 \%$ of those treated for syphilis before it was established it was transmitted by $\square$ syringes, and sterilisation by heat was imposed. ${ }^{36}$

After the war, the Lock never survived as a hospital; it was used for some years for administrative offices in the new National Health Service $\frac{0}{\varnothing}$ but is now boarded up and partially derelict.

DEVELOPMENT OF PENICILLIN

Meanwhile in the USA, thanks to Florey, penicillin was now in production. ${ }^{16} 17$ Mahoney and hiso colleagues had treated four seamen with syphilis at $\bar{c}$ Staten Island. ${ }^{37}$ Back at St Mary's Jack Suchet was:tentatively treating a variety of cases of venereal 3 disease with Fleming's penicillin; they both addressedi the MSSVD on the subject in $1944 .{ }^{38} 39$

As the war ended Harrison, now nearly 70 years old but not yet retired from the Ministry-and who had earlier endeavoured to organise consistent $\frac{D}{0}$ arrangements for the treatment of venereal diseases among the merchant seamen of the various allies, ${ }^{14} \mathrm{~N}$ was visiting the Lock Hospital to inquire into the results of a trial he had organized of a British formu-N lation of penicillin in oil-beeswax in the treatment of ${ }^{\mathrm{W}}$
gonorrhoea.

Early in 1946 a large conference of research $\stackrel{\varrho}{C}$ workers was called in Washington to present and discuss the already considerable accumulated experi-? ence of penicillin therapy of syphilis in the USA. I $\frac{0}{0}$ attended this meeting and its committees as the $\overrightarrow{\mathbb{D}}$ British Army observer and was able to present the $\frac{\text { Pे }}{\mathbb{D}}$ findings in some detail to the MSSVD very shortly응 after my return. ${ }^{41}$ 
CREATION OF THE WORLD HEALTH ORGANISATION

The United Nations replaced the League of Nations in 1945. The constitution of the new World Health Organisation was signed by the representatives of 61 countries at an International Health Conference held in New York in 1946. Pending ratification by member states an interim commission was formed until the organisation was fully established in 1948.

Dr Thorstein Guthe, an Olympic oarsman and Norwegian naval physician (fig 6) was on the secretariat of the commission and responsible for venereal infections. He had observed Mahoney's original four patients with syphilis who were treated with penicillin and his very considerable energy, astuteness, and organising capacity were fired with an obsessional enthusiasm for venereology which was highly contagious to all exposed to it.

Meanwhile the Union Internationale contre le Péril Vénérien convened an executive committee meeting in Paris in 1946 and the first post-war general assembly in the same city the following year. Both Colonel Harrison (a technical counsellor) and Dr Guthe attended this meeting (fig 7), at which penicillin therapy was discussed and Guthe outlined the future plans of the WHO. ${ }^{42}$

\section{ACTIVITIES OF THE WHO}

The new World Health Organisation was quickly established in the Palace of the former League of

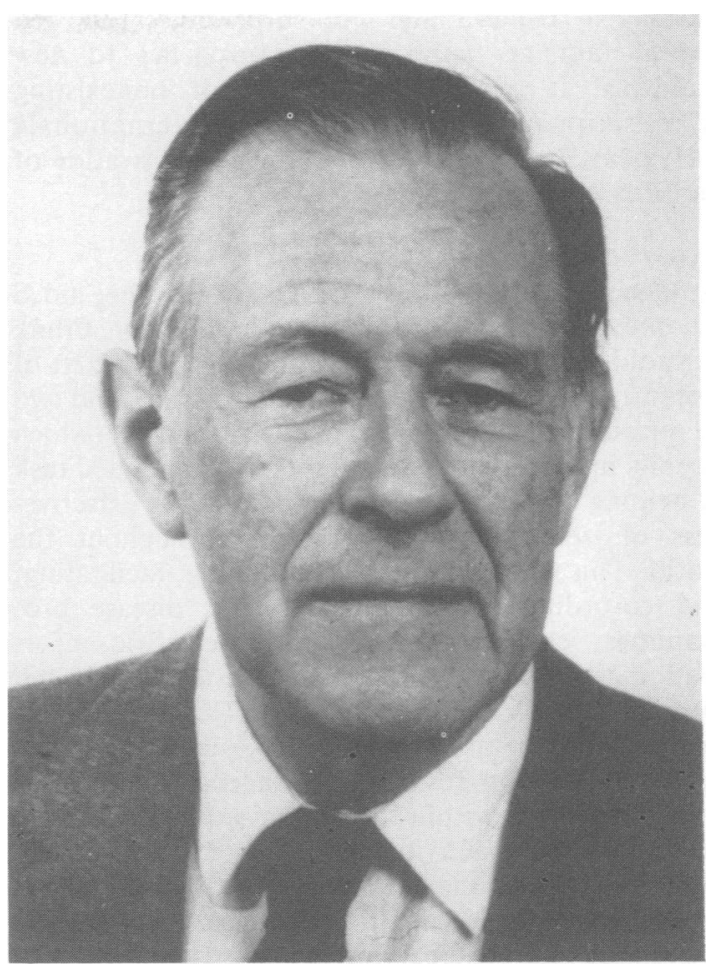

FIG 6 Thorstein Guthe

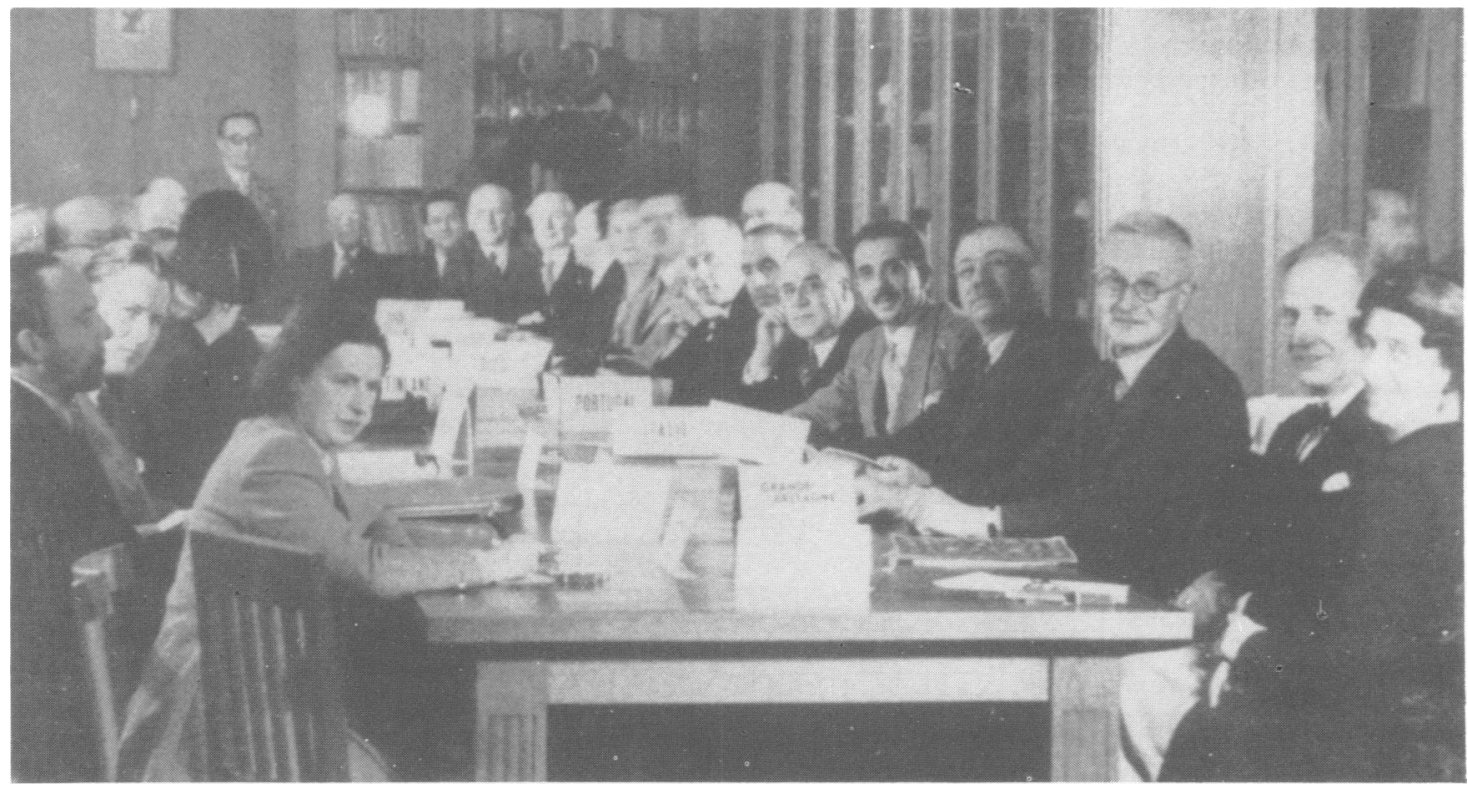

FIG 7 UIPV executive committee meeting, Paris 1947; Thorstein Guthe (seated third on the left of the table) and Colonel Harrison (seated third on the right) 
Nations in Geneva and not surprisingly followed several familiar paths in its approaches to new problems. It absorbed a number of pre-existing organisations including l'Office Internationale d'Hygiène Publique and with it the administration of the Brussels Agreement.

\section{WHO/VDT UNIT}

At Geneva the small VDT Unit under Guthe, aided by one physician (at first by the late Dr Frank Reynolds of the USA followed by Dr C J Hackett of Britain), one personal non-medical assistant, and two secretaries, plus an occasional consultant (which happily included me) set about its self-appointed task of helping others to raise the standards and effectiveness of venereal disease control throughout the world. This was achieved by stimulating, facilitating, and co-ordinating national venereal disease programmes, exchanging up-to-date scientific information (including training), and fostering research into all aspects of our specialty. This particularly involved co-operation with other established international and non-governmental agencies as well as with other units within the Organisation itself. First priority in these activities was the venereal and the non-venereal treponematoses in economically underdeveloped areas of high prevalence. ${ }^{43}$ An expert committee on venereal infections (treponematoses being soon added), with a sub-committee on the serological aspects, was then convened; an international serological laboratory was established at Copenhagen and a WHO international research laboratory at Baltimore. A more widely based WHO advisory panel of experts was gradually assembled.

\section{EXPLOITATION OF THE POTENTIALITIES OF} PENICILLIN

A first objective was to exploit to the full the potentialities of penicillin. One of the problems in

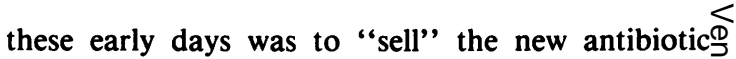
treatment for syphilis to European dermatovenereo- $\mathrm{D}$ logists entrenched and enriched by long-term treat- $-\underset{T}{ }$. ments with arsenic and heavy metals. This resistance. was very largely overcome by sending a WHO study $\overrightarrow{\vec{F}}$ commission to the USA ${ }^{44}$ (on which Dr Sydney Laird served) and at two regional symposia in Helsinki and $\frac{\bar{O}}{\circ}$ Paris in $1950 .{ }^{45}$

Workers in developing countries and areas of high $\vec{\Phi}$ prevalence of treponemal disease were more receptive and many WHO-assisted mass campaigns based on ${ }^{\infty}$ penicillin (fig 8) were organised, starting with $\vec{\circ}$ venereal syphilis in Poland, endemic syphilis in $\overrightarrow{-}$ Yugoslavia and Iraq, and yaws in Thailand, Haiti, $\omega$ the Philippines and Indonesia, in which millions ofos patients were examined and treated (fig 9). ${ }^{46}=$ Sufficient experience had accumulated from the yaws

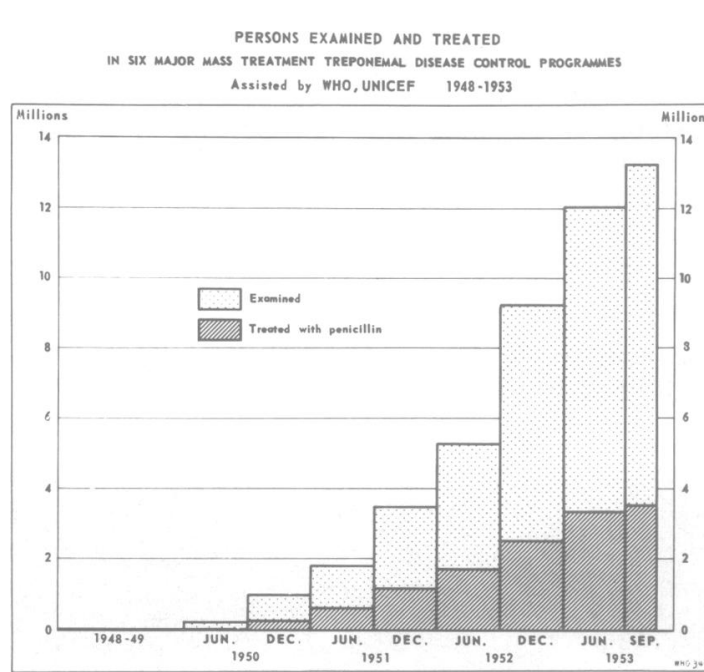

FIG 9 Increasing numbers treated in WHO campaigns

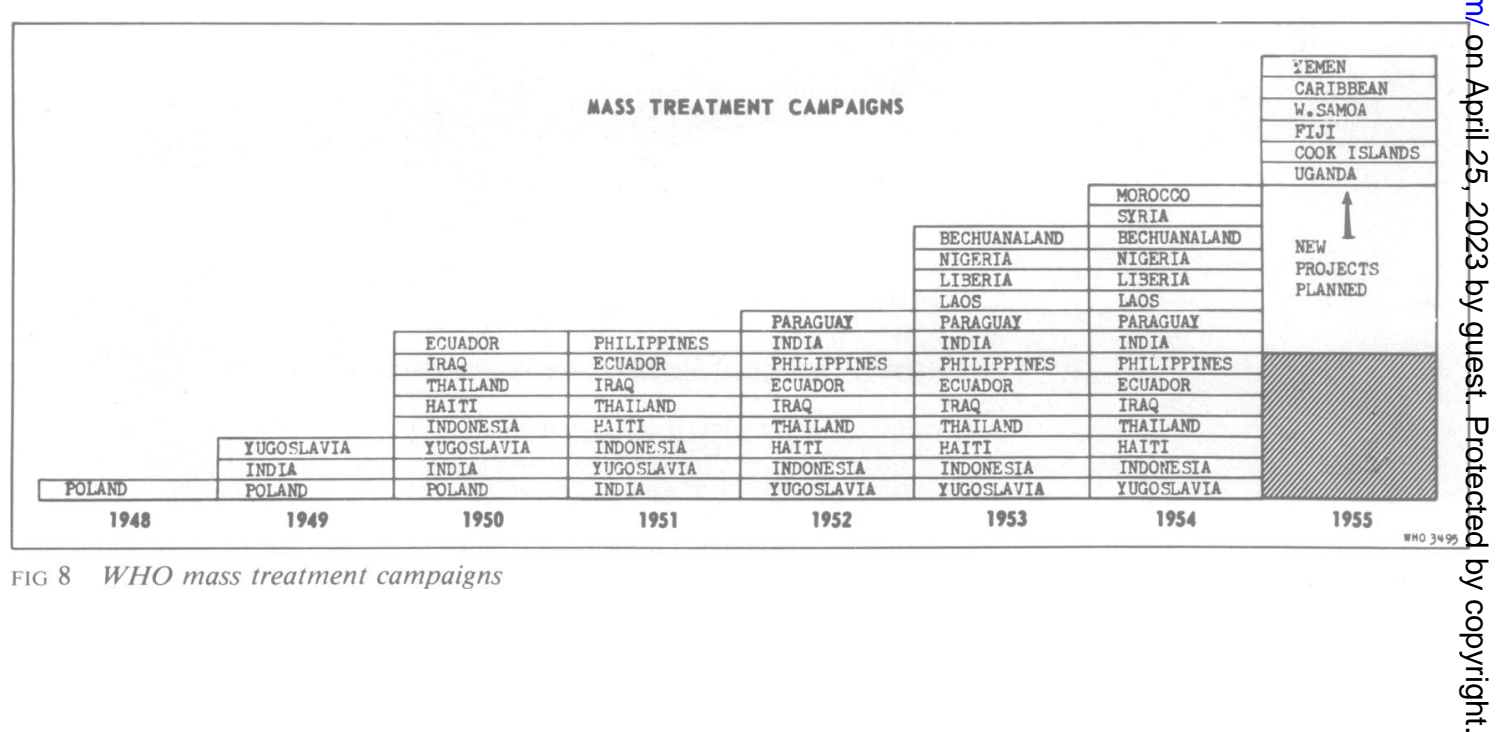


campaigns for international symposia to be held in Bangkok in $1952^{47}$ and in Ibadan in $1955,{ }^{48}$ both of which I had the privilege of attending.

\section{EXPERT COMMITTEES}

The momentum was maintained by repeated meetings of the expert committee in 1948 in Geneva and again in Paris; in 1949 in Washington ${ }^{43}$ (Dr McElligott, who had succeeded Colonel Harrison at the Ministry of Health in London, was then a member), in 1952 in London, ${ }^{45}$ and again in $1959^{49}$ in Geneva. A sub-committee on serological aspects met in Washington, ${ }^{50}$ Paris, ${ }^{51}$ and Copenhagen ${ }^{52}$ over this period. (The late Dr I N Orpwood Price, director of the Venereal Disease Reference Laboratory attended these).

Colonel Harrison, by now recently retired, was a member of the WHO expert advisory panel on serology and laboratory aspects and maintained a continuing interest in the international scene: Guthe visited him when in London. In 1950, in response to receiving the report of a venereal disease survey, undertaken by me for the then Government of
Southern Rhodesia ${ }^{53}$ during six months leave in what is now Zimbabwe, Harrison replied in a closely typed two-page letter from which, not just for reasons of vanity, the first and last paragraphs are reproduced (fig 10). The hopes expressed in the closing lines were not fulfilled, however, as it appears that in many respects the overall situation is in fact little changed today. ${ }^{54} 55$

\section{ACHIEVEMENTS OF THE WHO \\ Broad measures}

The achievements of the WHO in the first 10-15 years were considerable. Standard specifications of procaine penicillin in aluminium monostearate (PAM) were defined, and minimum treatment schedules for the treatment of syphilis and the non-venereal treponematoses based on this preparation were formulated. ${ }^{45}$ At Copenhagen reference preparations of cardiolipin and lecithin were made available, WHOdirected interlaboratory testing of freeze-dried sera organised (with reference centres in Denmark and the USA collaborating), and standard reference sera provided on demand. These activities replaced the

\section{COLONEI L W MARRISON}

Dr. R.R.WIIIcox, 224 Gloucester Terraco,, 2
68. ECCLESTON SQUARE. LONDON. $S$ W.I vicroma iass ¿1st Jure 1950

Dear $111 \operatorname{cox}$,

Thank-you very much for the copy of sour report on V.i. In Southern Rhodee18. I heve reed it with great laterost and ohould like to corgretulate you on its breadth and the sound rocomendations which you heve medo.

I hope jour repirt will be acted upon and titet you will heve the fleasure of knowing thet thereby you heve cade a big hole in the V.D. protiem in one pert of Africa at eny rete.

$$
\text { iinj regerso, }
$$

$$
\text { Yoiro sincerciy, }
$$

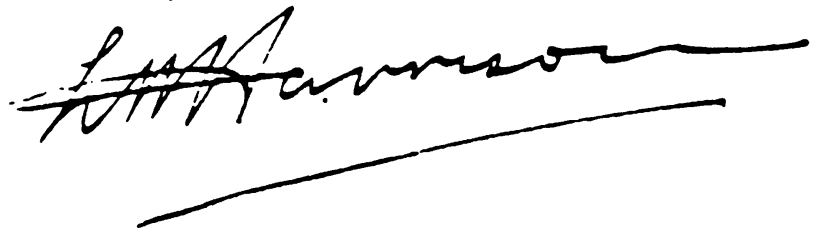

FIG 10 Colonel Harrison's letter to $\operatorname{Dr} R \quad R$ Willcox 
pre-war serological conferences of the League of Nations. At Baltimore basic research into the biology of treponematoses was undertaken, while in Guatemala a serological laboratory training centre was concerned in training and the standardisation of techniques. Also through the WHO the introduction of the Treponema pallidum immobilisation (TPI) test was guided in some 41 laboratories, mostly in Europe and the USA. ${ }^{56}$

\section{Maritime aspects}

The WHO formed a study group to clarify the Brussels Agreement (to which 67 authorities had now acceded or ratified while $\mathbf{3 0}$ others notified the WHO that free treatment was available in certain ports), ${ }^{57}$ introduced a new personal carnet, and published directories of VD treatment centres in ports. ${ }^{58} \mathrm{~A}$ Port Demonstration Centre was established in Rotterdam and used for the training of physicians.

An international antivenereal disease commission of the Rhine was established in 1949 to cater for the needs of the boatmen on this river, ${ }^{33} 58$ but the need for such a specialised organisation soon diminished and it was disbanded in 1953.

\section{Consultants and fellowships}

A number of other demonstration and training projects were instituted (fig 11) and other consultants were sent to project areas. Drs K R Hill, S M Laird, F R Curtis, G W Csonka, and the late 'Gobi' Jones (then working in the St Mary's clinic) were among those from this country.
Numerous fellowships (fig 12) were awarded for the training of physicians or key laboratorye personnel. One brought the late $\mathrm{C}$ W Chacko (who․․ was later killed in an aircrash while on a WHO? assignment) to St Mary's to establish the TPI test before taking it back to Bombay and later to Madras $-\frac{-}{0}$

Lecture courses were arranged through the regionaEoffices, such as those in Beirut and Rotterdam (the WHO regional office for Europe in those days wasp also in the Palais des Nations, Geneva), and a $\mathrm{WHO}_{0}^{\circ}$ travelling VD seminar spent some weeks studyinge methods in the USSR.

\section{Publications}

Monographs or similar volumes were published ones cardiolipin antigens, ${ }^{59}$ yaws ${ }^{60}$ and yaws control, ${ }^{4{ }_{C}}$. endemic syphilis, ${ }^{61}$ donovanosis, ${ }^{62}$ venereal disease legislation, ${ }^{63}$ treponematoses as a world problem, ${ }^{46}$ and their biology and research aspects, ${ }^{64}$ yaws nomenclature, ${ }^{65}$ and, in 1960 , its differentia $P$ diagnosis. ${ }^{66}$ In addition special numbers of the $\mathrm{WHO}^{-}$ Bulletin were organised and studies were made ofo penicillin reactions. ${ }^{67}$ Throughout, a long line of cyclostyled VDT/documents, which included muche not yet published research, flowed from Geneva tợ panel members and others interested on a worldwideo basis.

BRITISH CO-OPERATIVE CLINICAL GROUP Guthe stimulated me in 1952 to participate in forming the British Co-operative Clinical Group to undertake a study of the results of the treatment of syphilis with penicillin plus metallotherapy, which?

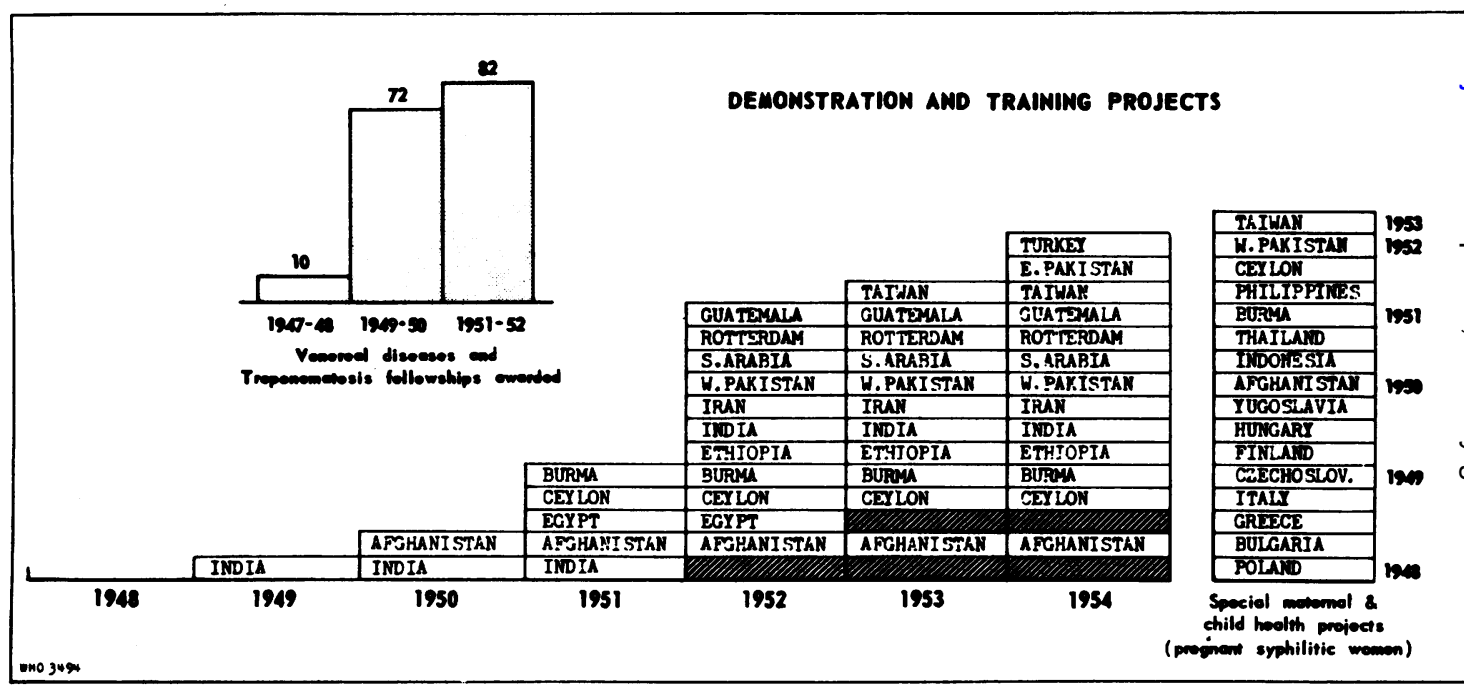

FIG 11 WHO demonstration and training projects 


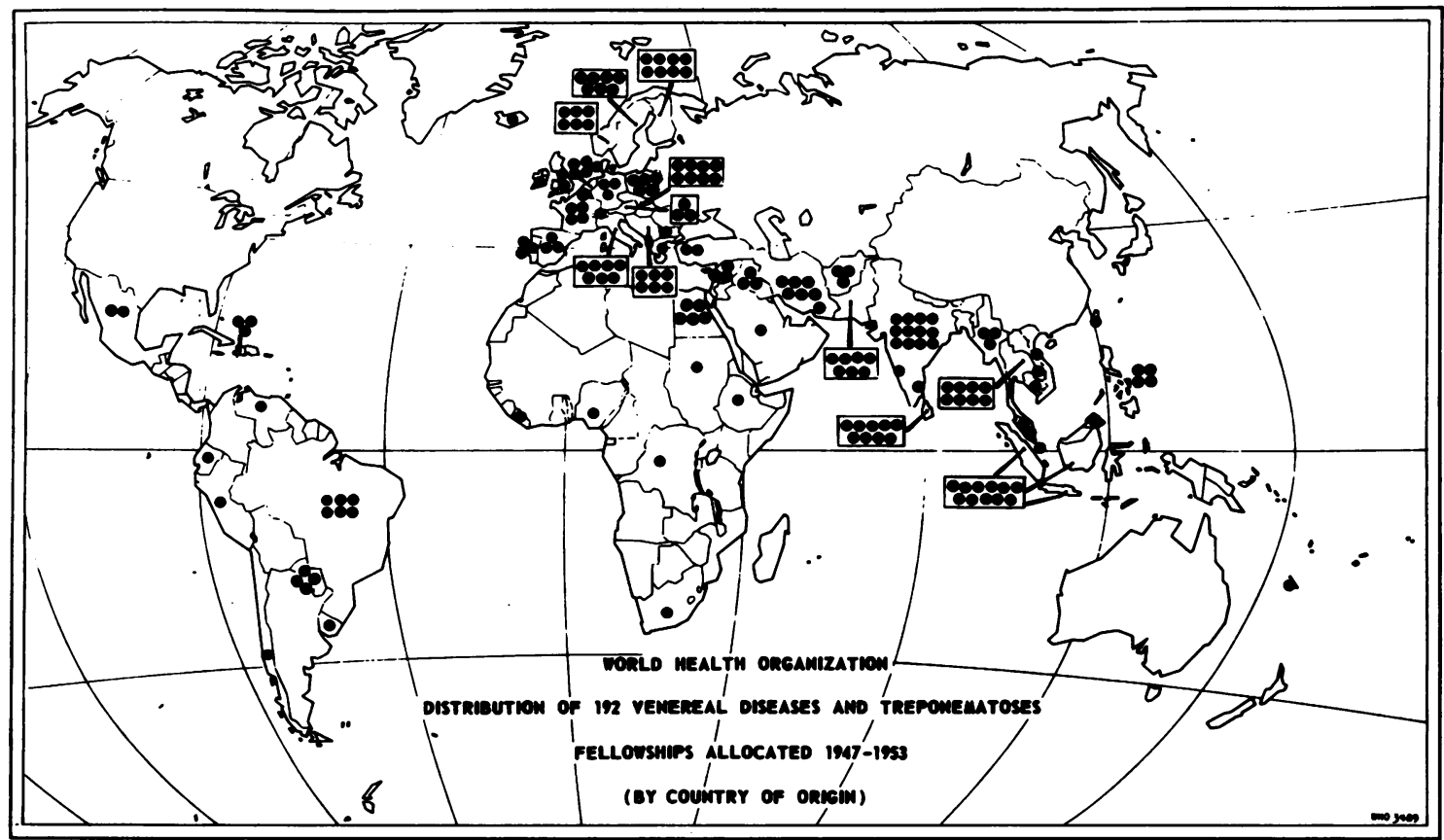

FIG 12 WHO fellowships allocated, 1947-53

had previously been used in Britain. Some 104 clinics participated in this study, and 9600 cards relating to cases of syphilis treated in 1946 were sent to the WHO. But like the League of Nations study 25 years before, it foundered in the hands of the statisticians and no firm conclusions could be drawn. The group also co-operated with the WHO in studies of penicillin blood concentrations and in the use of the newly arrived benzathine penicillin.

\section{OTHER INTERNATIONAL ACTIVITIES}

As syphilis became less prevalent, and the success of the mass campaigns was being evaluated, the problem of gonorrhoea and of non-specific urethritis was increasing.

The International Union (IUVDT), which had soon followed the WHO by adding 'and Treponematoses' to its title (and dropping Péril), held the first symposium on non-gonococcal urethritis in Monaco in 1954. This was attended by $\operatorname{Dr} A$ Cavaillon (1887-1967), with whom the Union had so long been associated, and by Dr A H Harkness with whose name the role of chlamydia in non-gonococcal urethritis will always be remembered. 68

The WHO organised broader based meetings in Tokyo in 1958 and with the IUVDT and United States Public Health Service in Washington in 1952 and again in-1962. Because of the alarm expressed by the expert committee in 1959 at the evident failure to control gonorrhoea, ${ }^{50}$ the WHO established an International Gonococcus Reference Laboratory in Copenhagen, convened a separate expert committee on gonococcal infections in Geneva in 1962,69 and planned for a meeting on Neisseria research to be held two years later. ${ }^{70}$

Our own MSSVD took wings with the first of its many overseas meetings in Paris in 1961 and its previous perhaps somewhat insular attitude was further broadened by the election of $\mathrm{Mr}$ Ambrose King as president of the IUVDT in 1962.

\section{Conclusions}

All the events which have been described occurred before the death of Harrison in 1964. Not to be forgotten in this story are the contributions of numerous other bodies international and national, governmental and non-governmental, including the Armed Forces, British Council, the Rockefeller Foundation, medical societies of other disciplines (dermatology, microbiology, epidemiology, behavioural sciences), and many individuals such as the late Dr J E Earle Moore of Baltimore, who have materially aided the international exchange of scientific information and views. 
Recommendations are one thing but their implementation is another, even if they are backed by legislation. Decrees, laws, regulations, or conventions, whether local, national, or international, are as nought unless heavily backed by the voluntary cooperation of those individuals expected to enforce them. Today, with the current multiplicity of international meetings involving a relatively small group of venereal disease specialists the opportunities for seeking such co-operation on a world-wide scale have, in theory, never been better. Whatever the problems, however, while the pace has undoubtedly quickened, it can safely be predicted that many international efforts made for their solution will strike familiar notes on the gongs of the past.

I am grateful to the librarians of the Royal College of Surgeons, the British Medical Association, the London School of Tropical Medicine and Hygiene, and St Mary's Hospital for their repeated assistance.

Figs 1,2 , and 4 are reproduced by kind permission of the Royal College of Physicians, fig 3 by kind permission of Heinemann Medical Books Ltd, and figs $8,9,11$, and 12 by kind permission of the World Health Organisation. I am grateful to $\operatorname{Dr} P \mathbf{N}$ Cardew of the Department of Audiovisual Communication, St Mary's Hospital, for providing fig 5.

\section{References}

1. Willcox RR. Venereal disease in the Bible. Br J Vener Dis 1949; 25:28-33.

2. Schokking $\mathrm{CPh}$. The Brussels Agreement in retrospect. In: Maritime Venereal-Disease Control: Selected Lectures, Rotterdam 1953-1954. Geneva: WHO Regional Office for Europe, 1956.

3. Abraham JJ. The early history of syphilis. Br J Surg 1944;32: 225-37.

4. Abraham JJ. Surgeon's Journey. London: Heinemann, 1957.

5. Farey W. The Lock Charity. Westway 1978; March:11.

6. Rugg-Price A. Paddington Workhouse and Infirmary 1846-1900. Westway 1974; June: 10-11.

7. Cope Z. The History of St. Mary's Medical School, London. London: Heinemann, 1954.

8. Lane JR, Gascoyen GG. Record of cases treated in the Lock Hospital by syphilization. Med Chir Trans 1867;281-328.

9. Lane JR. Lectures on Syphilis: delivered at the Harveian Society, December 1876. London: J \& A Churchill, 1878.

10. Scott GR. A History of Prostitution from Antiquity to the Present Day. London; T Werner Laurie, 1936.

11. Bullough V, Bullough BL. A History of Prostitution. New York: University Books, 1964.

12. League of Nations. Report of the Special Body of Experts on Traffic in Women and Children. Geneva: 1927;6-7.

13. Colebrook L. Almroth Wright-Provocative Doctor and Thinker. London: Heinemann Medical Books, 1954.

14. Harrison $\mathrm{LW}$. Half a lifetime in the management of venereal diseases. From chaos to order. Med Illustr 1949; July:318-24; Aug: 376-85.

15. Harrison $\mathrm{LW}$. The value of a scientific outlook to the worker in venereal diseases. Br J Vener Dis 1925; 1:81-5.

16. Fleming A. Demonstration of a simple method of serum diagnosis of syphilis by the "complement deviation" method. Proc $R$ Soc Med, 1909; 2:220-5.

17. Fleming A, Colebrook L. On the use of salvarsan in the treatment of syphilis. Lancet 1911;1631-4.
18. Maurois A. The Life of Sir Alexander Fleming. Discoverer of Penicillin. London: Jonathan Cape, 1959.

19. Crowther JG. Alexander Fleming. Heron Books, 1971.

20. Anonymous. International Bureaux. Encyclopedia Britannica $\frac{0}{\mathrm{e}}$. 1946; 12:515.

21. Royal Commission on Venereal Diseases. Final Report of the Commissioners. London: HMSO, 1916.

22. Harrison LW. The public health services and venereal diseases Br J Vener Dis 1925; 1: 12-22.

23. Anonymous. League of Nations. Encyclopedia Britannic 1946; 13: 829-44.

24. Harrison LW. Introductory remarks to demonstration of flocculation tests. Br J Vener Dis 1931; 7:89-97.

25. League of Nations Health Organization. Report of the Labora tory Conference on the Serodiagnosis of Syphilis, convened a $\mathrm{f}$ Montevideo by the Institute for the Prevention of Syphilis of Uruguay, 15-26 September 1930. Geneva, 1931.

26. Harrison LW. History of the Medical Society for the Study of Venereal Diseases (with a history of the Scottish Branch by RW Forgan), Br J Vener Dis 1961;37:2-32.

27. Harrison LW. The treatment of early syphilis. The enquiry and? recommendations of the League of Nations Health Organi zation. Br J Vener Dis 1935; 11:69-90.

28. Fleming $A$. On the antibacterial action of cultures of penicillium with special reference to their use in the isolation of $B$ influenzae. Br J Exper Pathol 1929; 10:226-36.

29. Jefferiss FJG, Willcox RR, James DT. The Hospital and Health Services Review 1974; 70:9-13.

30. Rice JL, Kalinski DJ, Farmer TP, Parran T. (report compiledby Clarke CW). Control of syphilis and gonorrhoea in Scandinavian countries and in Great Britain. Amer $J$ Syp 1936;20: 1-63. (see abstract by Harrison LW. Bull Hyg 1936 11:910).

31. Ministry of Health. Report on Anti-venereal measures ir certain Scandinavian Countries and Holland. London: HMSON 1938.

32. Harrison LW. Anti-venereal measures in Denmark an Sweden. Br J Vener Dis 1939; 15:1-17.

33. Hermans EH. The Rhine River Commission. In: Maritime Venereal Disease Control, Geneva: WHO Regional Office foD Europe, 1956:21-26.

34. Willcox RR. Textbook of Venereal Infections and Trepone matoses, 2nd ed. London: Heinemann 1964:424-5.

35. League of Nations Advisory Committee on Social Questions $\overrightarrow{\vec{F}}$ Prevention of Prostitution. A study of measures adopted of under consideration particularly with regard to minors? Geneva; League of Nations, 1943.

36. Willcox RR. The effects of syringe-transmitted jaundice on the outcome of the treatment of early syphilis. Br J Vener Dis 1947; 23:121-3.

37. Mahoney JF, Arnold DC, Harris A. Penicillin treatment of early syphilis. A preliminary report. Venereal Disease Infor-윽 mation 1943; $24: 355-7$.

38. Fleming A. Penicillin in venereal disease, part I. Br J Vener Diso 1944; 20: 133-6.

39. Suchet J. Penicillin in venereal diseases, part II. Br J Vener Dis 1944; 20: 136-8.

40. Ministry of Health. On the State of the Public Health during Six Years of War. London; HMSO 1946;66-73.

41. Willcox RR. Current trends in the treatment of venereal disease in the United States of America. Br J Vener Dis 1946;22: $102-11$.

42. Union Internationale contre le Péril Vénérien. Assemblée Générale, Paris 20-25 October 1947. Texte de Rapports eף Compte Rendu des Débats, Paris, 102-105.

43. World Health Organization. Expert Committee on Venerea Infections: Report of the Third Session. Tech Rep Ser No 13 वृ
Geneva; WHO, 1950.

44. World Health Organization. Venereal Disease Control in the USA: report of the WHO Study Commission. Tech Rep SeE No 15, Geneva; WHO, 1950.

45. World Health Organization. Expert Committee on Venerea Infections and Treponematoses. Fourth report. Tech Rep SerT No 63, Geneva; WHO, 1953.

46. Guthe T, Willcox RR. Treponematoses a World Problem. Chronicle of the WHO (special issue) 1954;8:37-114.

47. World Health Organization. First International Symposium on Yaws Control 1953. Monograph Series No 15, Geneva; WHO, 1953. 
48. Report of International Conference on Control of Yaws, Nigeria 1955. J Trop Med Hyg 1957;60:1-24.

49. World Health Organization. Expert Committee on Venereal Infections and Treponematoses: fifth report. Tech Rep Ser No 190, Geneva; WHO, 1960.

50. World Health Organization. Expert Committee on Venereal Infections: report on the First Session of the Sub-committee on Serology and Laboratory Aspects. Tech Rep Ser No 14, Geneva; WHO, 1950.

51. World Health Organization. Expert Committee on Venereal Infections and Treponematoses: report on the Second Session of the Sub-committee on Serology and Laboratory Aspects. Tech Rep Ser No 33, Geneva; WHO, 1951.

52. World Health Organization. Expert Committee on Venereal Infections and Treponematoses. Sub-committee on Serology and Laboratory Aspects: Third Report. Tech Rep Ser No 79, Geneva; WHO, 1954.

53. Willcox RR. Report of a Venereal Disease Survey of the African in Southern Rhodesia. Salisbury: Southern Rhodesian Government; 1949.

54. Latif AS. Sexually transmitted disease in clinic patients in Salisbury, Zimbabwe, Br J Vener Dis 1981;57: 181-3.

55. Bingham JS. Zimbabwe: land of hope and . . Br J Vener Dis 1981;57:184-6.

56. World Health Organization. The Medical Research Programme of the World Health Organization 1958-1963: report by the Director General, Geneva; WHO, 1964;77-91.

57. World Health Organization. The Agreement of Brussels 1924 respecting facilities to be given to merchant seamen for the treatment of venereal diseases. Report of a Study Group. Tech Rep Ser No 50, Geneva; WHO, 1958.
58. World Health Organization. World Directory of Venereal Disease Treatment Centres at Ports, 2nd ed, Geneva; WHO, 1961.

59. Pangborn MC, Almeida JO, Maltaner F, Silverstein AM, Thompson WR. Cardiolipin antigens. WHO Monogr Ser No 6, Geneva; WHO, 1951.

60. Hill KR, Kodijat R, Sardadi M. Atlas of framboesia. WHO Monogr Ser No 5, Geneva; WHO, 1951.

61. Grin EI. Epidemiology and control of endemic syphilis. WHO Monogr Ser No 17, Geneva; WHO, 1953.

62. Rajam RV, Rangiah PN. Donovanosis (granuloma inguinale, granuloma venereum). WHO Monogr Ser No 24. Geneva; WHO 1954.

63. World Health Organization. Venereal Diseases. A Survey of Existing Legislation. Geneva; WHO, 1956.

64. Turner TB, Hollander DH. Biology of the treponematoses. WHO Monogr Ser No 35, Geneva; WHO, 1957.

65. Hackett CJ. An international nomenclature of yaws lesions. WHO Monogr Ser No 36, Geneva; WHO, 1957.

66. Hackett CJ, Lowenthal LJA. Differential Diagnosis of Yaws. WHO Monogr Ser No 45, Geneva; WHO, 1960.

67. Guthe T, Idsфe $O$, Willcox RR. Untoward penicillin reactions. Bull WHO, 1958; 19:427-501.

68. Harkness AH. Non-gonococcal Urethritis. Edinburgh; Livingstone, 1950.

69. World Health Organization. WHO expert committee on gonococcal infections: first report. Tech Rep Ser No 262, Geneva; WHO, 1963.

70. World Health Organization. Meeting on Neisseria research: first report. Working document WHO/VDT/RES/Gon. 8.65. 